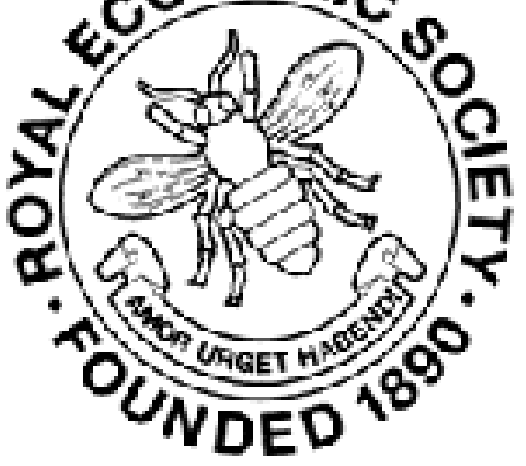

Peasant-Farming in Denmark

Author(s): Erik Givskov

Source: The Economic Journal, Vol. 13, No. 52 (Dec., 1903), pp. 645-653

Published by: Wiley on behalf of the Royal Economic Society

Stable URL: http://www.jstor.org/stable/2221349

Accessed: 26-06-2016 10:30 UTC

Your use of the JSTOR archive indicates your acceptance of the Terms \& Conditions of Use, available at

http://about.jstor.org/terms

JSTOR is a not-for-profit service that helps scholars, researchers, and students discover, use, and build upon a wide range of content in a trusted digital archive. We use information technology and tools to increase productivity and facilitate new forms of scholarship. For more information about JSTOR, please contact support@jstor.org.

Royal Economic Society, Wiley are collaborating with JSTOR to digitize, preserve and extend access to The Economic Journal 
that the houses in respect of which it is granted shall only be let to workpeople belonging to the Hanover Insurance Fund, and that an occupant of such a house shall have a right to purchase it and take it over as soon as he can pay one-third of the purchase price as fixed by the owner, the occupant, and the Insurance Authority. In this case the latter agrees to accept the new owner in the place of the old on the same terms and conditions. It is stipulated, however, that no workman can own more than one house containing two dwellings. The conditions which apply to loans granted to land-owners for the building of houses for agricultural labourers do not materially differ from those which apply to industrial dwellings, though here it is stipulated that, when a loan has been reduced to half the value of the property, the interest payable shall be either that usual in the locality or a minimum of 4 per cent., and that, where houses pass into the hands of labourers by purchase from their employers, the rate of interest payable to the Insurance Authority shall be $3 \frac{1}{4}$ per cent. up to twothirds of the entire value, with $1 \frac{3}{4}$ per cent. by way of repayment. The spirited example which has been set by Hanover is proving in Germany a valuable object lesson in the manner in which the enormous sums of money which have been accumulated under the Industrial Insurance Laws, can be employed with special advantage to the working classes, by whose contributions they are so largely created.

William Harbutt Dawson

\section{Peasant-farming in Denmark}

WeLLington is reputed, very likely without foundation, to have said that the battle of Waterloo was gained on the play-grounds of Eton. Whether this is so or not may be disputed; but it is beyond contradiction that the victories of the Danish farmers have been gained at the High Schools and Agricultural Schools of the country. Great as these peaceable victories have been in time gone by, we may now look to Denmark with the certain expectation of further developments, a new army of intelligent and educated workers, consisting of nearly 200,000 peasant farmers, having entered the field. Until quite recently the whole, or nearly the whole, of the agricultural prosperity of Denmark was borne by the farmers possessing from 10 to 100 acres of land by the aid of co-operation - that is to say, hardly more than 100,000 farmers, all told, contributed to this prosperity, while the peasant farmer's life, as also his mental equipment, left a good deal to be desired. During the last ten to twenty years he has been advancing fast in prosperity and intellect; but before describing the progress lately obtained, it may be desirable to give a brief sketch of

No. 52.-VOL. XIII. 
the historical and economic conditions out of which the Danish peasant farmers evolved.

When a little more than a hundred years ago the yoke of bondage was lifted from the shoulders of the Danish peasant, it was only the farmers who were in a position to reap any lasting benefit by the liberation. To a certain number of the cottagers, indeed, small freehold plots were given, but the majority did not obtain any holding, and had to procure one as best they could. And the proprietors of the larger estates, who, by the commutation of villenage, concomitant with the liberation from bondage, had lost the labour of the farmers, were glad to obtain cheap labour by granting small plots on the outskirts of their farms to such as were anxious to obtain them against paying labour-rent. Thus the yoke of serfdom had only been shifted from the farmers on to the shoulders of the cottagers. The wave of freedom rolling over Europe in 1848 carried away with it these labour rents, but, unfortunately, only to substitute lease on half-yearly agreement, and without giving at the same time to the tenant any compensation for improvements made by him. It was not until quite recently that this injustice has been removed.

But, nevertheless, in the fertile soil of political freedom the number of freehold peasant farmers increased steadily. Still, it was not till agricultural co-operation had been well established in the country that it was able to do anything for the economic freedom of the peasant farmers. They were not exactly badly off, but their life was coarse and dreary in the extreme, and they had neither leisure nor desire to acquire any enlightenment beyond the elementary teaching of the village schoolmaster.

During the last ten to twenty years all this, however, has been changed. By co-operation they obtain all the advantages which the great farmer gets from his large holding, while at the same time they naturally cultivate their land with far greater care than the farmers. Consequently, acre for acre, they obtain a much larger return from the soil, with the natural result that the small holdings in Denmark to day are proportionately 50 per cent. more valuable than the farmers' larger holdings. In fact, while owing to the over-sea competition the large farms show an actual decrease in value of from 15 to 30 per cent. during the last twenty years, the small holdings have in the same period increased from 20 to 35 per cent. At the same time, the general meetings of the agricultural co-operative societies, where the big farmer and the cottager meet each other as equals, have done a great deal to raise the spirits of the latter.

In short, the last twenty years have witnessed a great improvement in the condition of life all round of the Danish peasant farmer. Still, it is only the last few years-ten at most-in which the effects of this state of things have made themselves felt, and this not only in the betterment of the economic condition of the peasant farmer, but also in a conscious intention of the legislative authorities to do their best 
to raise the level of the class in its entirety, and also to increase the number of peasant farmers. One of the fruits of this intention is embodied in a law of 1899 for the providing of land to cottagers.

It is a question that, from various points of view, is open to argument, whether such legislation is capable of effecting any good, and there is probably not a single country in Europe where the peasants have shown any great desire to obtain the homesteads thus offered by the Governments. In Denmark, the size of the homesteads varies, according to the quality of the soil, from three to eleven acres, and may be granted to the agricultural labourer who can provide one-tenth of the capital necessary to the purchase of land with buildings and stock, the Government advancing the nine-tenths on easy terms. An amount of $£ 100,000$ has been set aside annually for five years, and by this about one thousand peasant farmers may be created yearly. It remains, however, to be seen how far such a partial adoption of the socialistic principle of State aid, with all the consequent restrictions and limitations to the free activity of the individual, will work any good. This much may be said, that hitherto only a comparatively small number of labourers have availed themselves of the facilities offered them by the law, and thus the increase in rent, that would have been inevitable if a great demand for land had been created, so far has not made itself felt.

At all events, it is a tolerably well intentioned attempt to come to the aid of the lower classes in order to place the greatest possible number in a position to earn their living as independent agriculturists; and so far it only converges with the general tendency at work in the country at the present day. This tendency has increased the cultivated area of Denmark from 3,784,000 acres in 1875 to $4,360,000$ acres in 1896, and out of an adult male population of about 550,000 it has created an army of peasant-farmers, numbering nearly 200,000 . It is a natural outgrowth of co-operation.

Co-operation, however, has not all the honour of having effected this. The State, societies, and private individuals have all vied with each other in carrying out measures well suited to improve the condition of the peasant-farmers, and in this way increase the incentive amongst the labouring classes to enter the ranks of the small holders, because it has long been clearly perceived, that only in the greatest possible extension of this class of citizens can be found a sound base for the State of the future.

Simply increasing their numbers would, however, not do much good. Only by equipping them for a successful struggle for life, by educating them intellectually and technically, has it been possible to get so far that it has been clearly proved what immense bars of mental gold a nation can dig from its own subsoil, from the lower classes, when economic freedom has been ensured to them. And the peasant-farmers are awakening. All over the country have sprung up peasant-farmers' associations, having their own organ in the Press, 
The Peasant-Farmer, for the purpose of promoting the interests of their class, and improving the cultivation of small holdings ; while many a good man has stepped out from their rank to take his seat in the Danish Parliament. But much is still left to be done, and the result of the efforts of the last ten to fifteen years has not yet made itself fully felt, all good seed requiring time to grow and ripen. A short sketch of what has been done during this period may, however, not be out of place, because it is this work that has prepared the soil for the last few years' truly democratic development and general prosperity of the country. It is this democratic tendency which has justified the Danish Minister of Agriculture in stating in a recent speech that, in spite of the world-wide depression, the last four years have been the most prosperous Danish agriculture ever knew, thanks to the small holders.

While, as before stated, it is more than a hundred years since the farmers of Denmark were liberated from serfdom, it is really only during the last generation that the yoke of bondage has been slowly lifted off the shoulders of the peasant-farmers, although they were politically free since 1848. Therefore the agricultural co-operation in Denmark which has set the world marvelling, originated with, and was carried out by, the farmers of holdings from, say, 10 to 100 acres. They had leisure and money enough to grasp the opportunities offered by the high schools and the agricultural schools which abound in the country, and they soon turned the enlightenment and skill acquired there to the best of purposes in cultivating their land with greatly increased ability. At the same time, the Royal Agricultural Society and the Royal College of Agriculture did much to diffuse knowledge as to new methods and the results obtained by the experimental farming carried on by these institutions. But all this instruction was, and partly is, beyond the means of the peasant-farmer; if he could afford to send a son to a high school it was with the intention to enable him to try his fortune in other and higher walks of life. To the son who was designated to inherit the holding, the common school was good enough. Not till the last twenty years did any change take place in this state of things; but the better economic conditions, consequent upon the peasant-farmers being enabled to share in the benefit of co-operation, have naturally aroused in them a desire for learning, and so we now see numbers of the young sons and daughters of the small farmers in the school room of the high school.

While the agricultural schools and the Royal College of Agriculture present very nearly the same features as similar institutions abroad, the high schools, so to speak, have grown out of the Danish soil, andin spite of the great success they have had, and the great benefit they have conferred on the people-have hardly been imitated outside the three Scandinavian countries. Having now developed into something like a final stage of education for all the young folk from the countryside, it is well within the purpose of this paper to bestow a few lines 
on them in order to show how intensely well suited they are to play their part, to spread enlightenment to the remotest cot of the country.

There are at the present time in existence 70 of these high schools, in which, in 1901, were taught 6,370 pupils from 18 to 25 years. A feature which essentially contributes to the good results obtained by these high schools is, that young people from the different parts of the country frequent the same school and live together there, exchanging views and opinions. By this, much provincial narrow-mindedness is removed, and by promoting a good understanding between the different classes of society the high schools also do good work. Although the majority of the pupils belong to the agricultural classes, there is still some social difference between the farmer's son and the hind, between the farmer's daughter and the seamstress or the dairymaid. That the high schools have contributed largely to remove the barriers raised by social prejudice, and by friendships contracted under the popular democratic influence of the schools, have bridged over the gulf which sunder different sections of the community, is certainly not their least merit.

It will be imagined, therefore, that the high schools have not been working among the people during the period of 50 years without to a very great extent leaving their mark on the whole social fabric. There is no doubt that the great capability exhibited by the Danish farmers during the last 25 years of the nineteentb century is to a very essential degree due to the high schools. To illustrate to what an extent they have been the leaven of public life, it will be enough to say, that out of the 58 peasants who sat in the recently dissolved Danish Parliament no fewer than 35, or one-third of the whole house, had passed through these high schools.

Exceptionally low as the cost of a stay at these high schools is, it is, however, still more than a goodly number of peasant-farmers can afford to pay for their children and far beyond the means of most of the mere agricultural labourers, who in latter life swell the ranks of the peasant-farmers. Therefore, it is only natural that with the growing prosperity of these, the bottom-layer of the agricultural population, the craving for intellectual development has given itself expression in a new kind of schools specially suited to meet the requirements of the agricultural labourer, the cottager and the peasant-farmer.

These schools which possess some possibility of being the lever that will lift not only the poor little bit of Danish economic life but the whole fabric of the entire European civilisation a few steps upwards have, however, such a claim to attention, that it may be deemed desirable briefly to map out the different steps in the develop. ment of the conditions of the peasant-farmers which have led up to the establishment of the schools.

It goes without saying that in a democratic country like Denmark, where the social difference between the farmer and the peasant. farmer is nearly effaced, there must of necessity be already a 
great number of intellectually well equipped peasant-farmers. And so there is; there are peasant-farmers personally known to the author who from their 15 acres of land produce more milk, bacon, and eggs than many a great farmer, and whose only complaint is, "that they really have too much land"; there are peasant farmers who, having for years been teachers at the high schools, of their own free will have preferred the independent and happy life of a small freeholder, and now till their three or four acres of land in the summer and take their seat besides the counts and barons of the Upper House during the winter. And there are peasant-farmers - actual peasant-farmers-who out of the surplus of their small holdings can, and do, defray the cost of lecturetours all over the country, and at the same time from their own orchard distribute gratis young fruit-trees to fellow peasants to the value of more than $\$ 100$ annually.

These, of course, are the exceptions, the most advanced; but they are steadily growing in numbers. And much has been done during the last fifteen to twenty years to elevate the standard of the peasantfarmers by means of summer trips arranged by the agricultural societies, in which annually about 500 peasant-farmers participate, and during which they, under expert guidance, are shown over the best cultivated small holdings of the country, finishing off by some practical lectures. These travels, together with prizes distributed for a number of years by the Royal Agricultural Society to the best tilled small holdings, have done a great deal of good, particularly by catching hold of the present generation of peasant-farmers and teaching them the improved methods of production; but the good that can be done in this way is naturally limited to a comparatively small number, and even this number can only be instructed to a rather limited extent during the fortnight these travels last, while at the same time the question of educating the coming generation of peasant-farmers is left entirely unapproached.

Another institution doing much good is the schools in handicraft, established in the Danish army. So much skill has been acquired by the pupils, of which the great majority belong to the farming classes, as to benefit them greatly in after life by making them independent of the village artisan and keeping them away from the public-house.

These and other similar measures have gone a long way to spread enlightenment and skill among the peasant farmers, but what they wanted, and what they have now got, were schools where their young folk could obtain general and technical knowledge at the same time, in short, a combination of the high schools and the agricultural schools, the latter being adapted for the special requirements of the small holder, and last but not least without any direct expense to him. It is already a great sacrifice, when a young hind or a young servant-girl devotes half a year of life and renounces earning any wages during this time in order to acquire knowledge; it would be unjust to expect them further to employ for this purpose their small 
savings, for which they will have ample use when they buy their own holding.

The essential condition for establishing such a school, therefore, must be that the public in some way furnishes the requisite means and that is also what has taken place. Partly by the Government and partly by the county councils sufficient amounts have been placed at the disposal of the peasant-farmers for such purpose. It will, therefore, now be time shortly to describe these schools.

While the instruction in the ordinary high schools does not include any instruction in agriculture, the instruction in the agricultural schools - apart from being too theoretical for the small holder-is mainly intended for large holders and, therefore, not suited for the peasants. But in the new high schools for peasant-farmers these two different kinds of instruction are given concurrently. Besides the ordinary courses for young men and women, short fortnightly courses are given to peasant-farmers and their wives, the most prominent feature being of course that particular stress is laid upon such instruction as will prove useful for the small farmer, and especially upon the utilisation of the by-products of agriculture and petty industry.

It is not too much to say that very high hopes are entertained as to the benefit which these schools will confer upon the peasant-farmers, and one is justified at least in predicting that one feature in the scheme will prove an incalculable boon to the small holders and to the country at large. That is the great importance attached to petty industries. The economic tendency of our time appears to be toward each nation providing itself as far as possible with every commodity that can possibly be produced within the country. And the day may not be so very far off, when this tendency will have taught England the necessity of taxing her land values in order to open up the land for the producers of her necessaries of life. Then Denmark will have lost her best market_in fact, almost her only market-for agricultural produce, and will consequently be compelled to produce at home many of the commodities which she now purchases with the products of her agriculture. But that means that she will have some day to revert to petty industry, the conditions for industry on a large scale not being very propitious in a country not producing coal and iron. She will then, however, possess not only an army of workers already trained for the exigency but also the whole machinery of co-operation will be at her disposal and will enable the people employed in the petty industry to produce, buy, and sell to the greatest advantage. And more than that: she will in her co-operative dairies, which to a number of almost 1,100 are spread all over the country, have a source of unused power, great enough to drive the loom and the bench of the village-industrials - the dairies being only used for their present purposes in the early morning and forenoon.

Would it not be worth while to take up a similar line in England? She has in the Agricultural Organisation Society a body of men able to do so. 
I should not consider this sketch complete without mentioning that the Danish farmers, to a great extent thanks to the efforts of the FreeTrader, Mr. Peschcke Köedt, are staunch opponents of any kind of "protection" of their industry, and that a great part of their success must be ascribed to the non-existence of protective duties on agricultural products. Thereby they have been able to obtain the raw material of their production without any unnecessary and hampering increase in price. Just to show the consequence it may not be without interest to compare the development of the exports of Denmark with those of the neighbouring country of Sweden, where protective duties are supposed to assist the farmer.

The duty on maize, which has increased the price of this very useful fodder-stuff, has reduced the export from Sweden of eggs from $£ 333,000$ in 1887 to hardly $£ 10,000$ now, while in Denmark, where maize has been obtained at the cheapest possible rates the export has increased from about $£ 100,000$ in the early 'eighties to $£ 1,400,000$ now. The duty on bacon, in connection with the maize duty, has in Sweden changed a surplus export of bacon of 3,000,000 kilo in 1893 into a surplus import of $9 \frac{1}{2}$ mill. kilo in 1900 , while in Denmark the surplus export has increased from $27 \frac{1}{2}$ mill. kilo, value $£ 1,300,000$ in 1890 , to $63 \frac{1}{2}$ mill. kilo, value $£ 3,300,000$ in 1900 . The duty on maize and a duty on butter has caused the export of Swedish butter to decrease from 25 mill. kilo in 1896 to 19 mill. kilo in 1900, while the Danish export has increased from 51 mill. kilo, of a value of $\$ 5,150,000$ in 1896 , to $62 \frac{1}{2}$ mill. kilo, value $£ 6,660,000$ in 1900 .

I do not feel at all convinced that such an enormous export of the agricultural products of a country is a thing to be much desired. Even though the fertility may be maintained by artificial means, the export is bound to raise prices for the home-consumption, while an ever increasing part of the profit tends to be retained by nonproducers, and spent in the purchase of luxuries for the idle, not in commodities that will increase the well-being of the producers. But as such export appears to be the prize for which all nations are vying, the figures above at all events prove the ability of the Danish peasant-farmer to be ahead of his competitors.

It cannot, however, be denied, that there is a great national danger -apart from the economic consequences-in all this prosperity. In order to obtain ready cash to carry out all the improvements required to keep up an ever increasing production, the Danish farmers have been mortgaging their farms through the well-known credit associations to the amount of $£ 50,000,000$, or about $£ 55,000$ for each little rural parish of the whole country. But the bonds of these credit associations are eagerly bought up by foreign, mainly German, capitalists. Therefore the result is that the more prosperous the farmers become the more of the Danish soil is sold to the German monied power, and an ever increasing part of the Danish export is simply interest paid on these bonds. Unless by taxation of land values the land is retained for the 
use of the producers the prosperity must of necessity come to a stop some day or other. This the peasant-farmers have clearly perceived, and they are, therefore, to a man zealous single-taxers. Their organisation, however, is too new to permit them of having obtained political power in proportion to their numbers. But it is only a question of time when they will have obtained it, and one is, therefore, fully justified in expressing the belief that prosperity will continue, and that the small farms of Denmark, as of yore, will in the future grow not only corn but also men, who will be ready. for any emergency, even for the most fateful of all-that England; by some day being able to grow her own food, should close her market for the Danish products.

ERIK Givskov.

\section{City Notes}

WE receive the following City notes from R. G. :-

The Set-back in Consols.-The contribution of "City Notes" was intermitted in September last, a lull having been experienced in business after the fall of Consols earlier in the year; but shortly after, the disease in Consols and in all gilt-edged securities, especially municipal and colonial loans, broke out afresh. The earlier fall in Consols had been from about 94 to 90 with a recovery to 91 ; but now there was a fresh fall to 87 with a recovery to $88 \frac{1}{2}$. This has been accompanied by a good deal of excitement, aggravated by apprehensions of dearer money; by actual panic or semi-panic in Wall Street, where trust shares and railway securities gave way from time to time as if nothing would stop the fall ; and by a similar panic in South African mining securities at home. Many explanations have been forthcoming, but they are all summed up in the word "liquidation," which seems inevitable after a great boom of any sort, and which readers of these notes have been led to expect for the last two years and more. It is impossible, for various reasons, to pronounce the liquidation as even yet at an end, though in some directions, perhaps, especially in Consols and South African securities, the worst may be over.

The Morgan Financing.-The principal reason for doubting whether the liquidation is quite over is the uncertainty respecting the Steel Trust, and the trust financing generally. The public in New York have been greatly excited by disclosures in suits for winding up the Shipbuilding Trust which affect some of the leaders in the financing of the famous Shipping Combine and of the Steel Trust itself. Excitement has been likewise promoted by the declared inability of the Steel Trust to keep its works in full employment and to maintain 